Федеральное государственное бюджетное обравовательное учреждение высшего образования «Адыгейский государственный университет»

М.Н. КАГАЗЕЖЕВ, Л.Л. БАГОВА

\title{
СБОРНИК ЗАААЧ
}

ПРИРОДОВЕДЧЕСКОГО

СОДЕРЖАНИЯ

учебно-методическое пособие

для учителей начальных классов 


\section{ББК 74.262я72}

\section{K12}

Кагазежев, М.Н.

К 12 Сборник задач природоведческого содержания: учебно-методическое пособие для учителей начальных классов [Электронный ресурс]: / М.Н. Кагазежев, Л.Л. Багова - Электрон. дан. (3,5 Мб). - Майкоп: ЭлИТ, 2016. - 1 электрон. опт. диск (CD-R). doi: 10.18411/elit-013.

\section{http://www.dx.doi.org/10.18411/elit-013}

\section{Публикуется по решению редакционно-издательского совета} ФГБОУ ВО «Адыгейский государственный университет»

Буркова Л.Л. Панеш Б.Х.

Кагазежев М.Н.

\section{РЕЦЕНЗЕНТЫ:}

- кандидат педагогических наук, доцент

- кандидат педагогических наук, доцент

\section{АВТОРЫ:}

- кандидат педагогических наук, доцент кафедры естественно-математических дисциплин и методики их преподавания в системе дошкольного и начального образования Адыгейского государственного университета, г. Майкоп

Багова Л.Л.

- кандидат педагогических наук, доцент кафедры естественно-математических дисциплин и методики их преподавания в системе дошкольного и начального образования Адыгейского государственного университета, г. Майкоп

В данном пособии излагается материал по применению задач природоведческого содержания на уроках математики в начальных классах.

Печатное издание вышло в 2012 году.

УДК 373.3.016:51(075.3) ББК 74.262я72 


\section{ОГЛАВЛЕНИЕ}

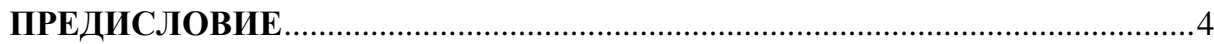

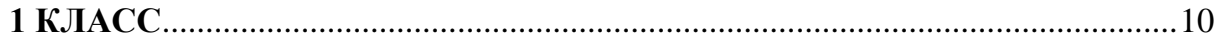

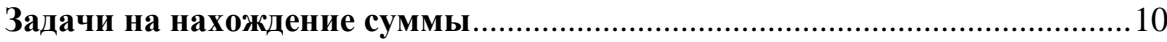

Задачи на увеличение и уменьшение числа на несколько единиц .............11

Задачи на нахождение неизвестного вычитаемого, слагаемого,

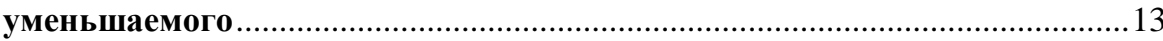

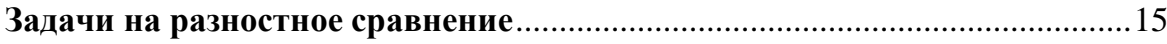

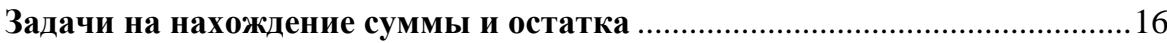

Задачи на закрепление пройденного материала ………............................... 18

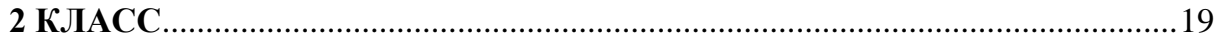

Простые задачи на умножение..................................................................... 19

Задачи на увеличение и уменьшение числа в несколько раз ……...............19

Задачи на деление по содержанию и на равные части ................................22

Простые и составные задачи на кратное и разностное сравнение ...........22

Задачи на приведение к единицы и на нахождение суммы двух

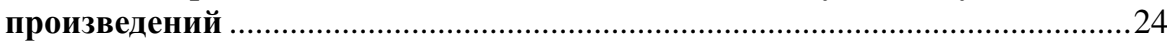

Задачи на нахождение уменьшаемого, вычитаемого, разности и на

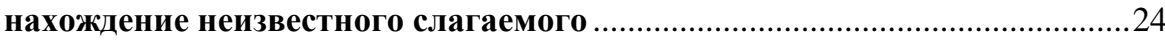

Задачи на нахождение числа по доле и доли по числу ................................26

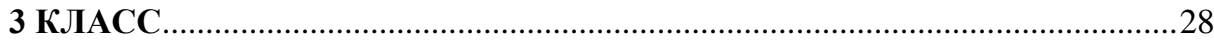

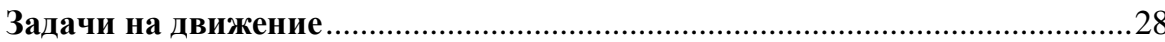

Задачи на пропорциональное деление и нахождение числа по доле и доли

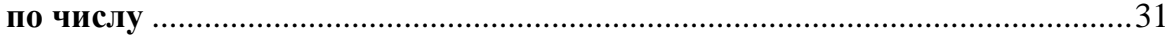

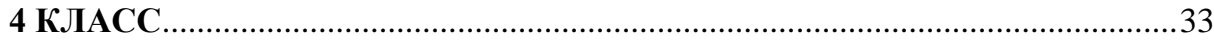

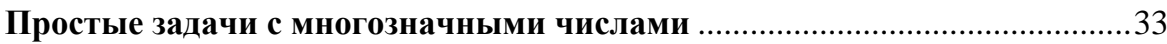

Составные задачи с многозначными числами ................................................

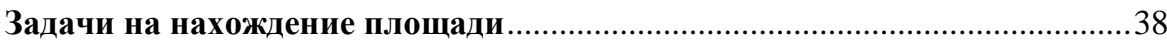

МАТЕРИАЛ ДЛЯ СОСТАВЛЕНИЯ ЗАДАЧ ПРИРОДОВЕДЧЕСКОГО

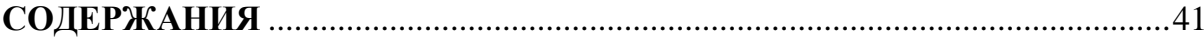

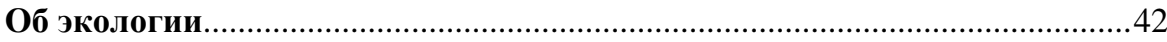

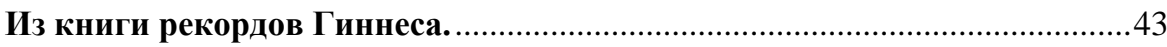

Задачи на уроках природоведения 4 класс

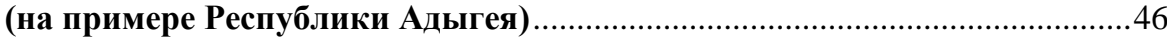

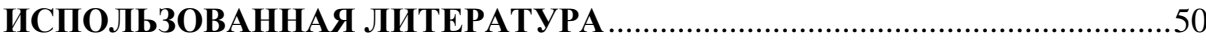




\section{ПРЕДИСЛОВИЕ}

Важнейшим аспектом в решении вопроса сохранения природных ресурсов Земли является образование людей в области окружающей среды, экологического воспитания всего населения и особенно подрастающего поколения. Под экологическим образованием понимается непрерывный процесс обучения, воспитания и развития личности, направленный на формирование системы научных и практических знаний и умений, ценностных ориентаций, поведения и деятельности, обеспечивающих ответственное отношение к окружающей социально-природной среде. Реальным выражением ответственного отношения к природе является обладание экологической культурой.

В системе экологического образования и воспитания исключительно важную роль играет школа, где экологическое образование должно носить непрерывный, интегрированный характер и осуществляться в течение всей жизни человека, начиная с дошкольного возраста. Особенно огромное значение для экологического образования и воспитания приобретает период обучения детей в начальной школе, где делают первые значительные шаги по изучению и общению детей с природой. Именно начальная школа является одним из первых звеньев становления человека - гражданина, где закладываются основы экологической культуры, формируется научно-обоснованное отношение к природной среде.

Анализ программ начальной школы позволяет выделить знания о природе практически во всех учебных предметах. Экологические знания могут также внедряться и на уроках математики.

Текстовые задачи, содержащие данные природоведческого характера, позволяют сделать более доступным для усвоения цифровой материал по экологии. При составлении задач, содержащих сведения природоведческого характера, материал 
может быть взят не только из географических источников, справочников, но также и получен самими учащимися при изучении объектов природы во время экскурсий. Главное - экологический принцип должен быть определяющим при составлении задач. В каждый урок математики нужно включать хотя бы одну задачу, знакомящую с элементами природы или рассказывающую об охране природы.

В представленном сборнике при подборе и составлении текстовых задач, а также их последовательности, мы исходили из программы начальной математики и учета принципов дидактики. Пользуясь данным сборником, учитель имеет возможность выбирать ту или иную задачу в зависимости от целей и задач урока. Кроме того, использование этих задач позволяет строить интегрированные уроки математики и окружающего мира, что повышает его познавательное значение, активизирует деятельность учащихся, пробуждает в них интерес к познанию жизни природы, а учителю предоставляет возможность показать свой профессионализм.

Надеемся, что предлагаемое пособие будет полезным для учителей начальных классов. 


\section{ПОНЯТИЯ, \\ ИСПОЛЬЗУЕМЫЕ В ЗАДАЧАХ ДАННОГО СБОРНИКА}

Айсберг

- это очень большой свободно плавающий кусок льда в океане или в море.

Альбатросы - это род морских кочующих птиц.

Бактерии

- это большая группа микроскопических организмов, преимущественно одноклеточных.

Бамбук

- это высокое и гибкое тропическое и субтропическое растение, древовидный злак с крепким полым стеблем.

Буревестник - это крупная морская водоплавающая птица, с длинными, узкими и острыми крыльями.

Бычки

- это небольшая морская рыбка, живёт в солоноватых водах.

Bаран - - это самый крупный вид ящерицы.

Вольер - это огороженная сеткой площадка для содержания птиц, кроликов и др.

Taza

- это северная морская птица из семейства нырков, с нежным, лёгким и ценным пухом.

Галера

- это деревянное гребное военное судно, созданное в 7 в. венецианцами.

Гектар $\quad-$ это единица площади в метрической системе мер, применяемая для измерений земельных участков. 
Горилль — - это самая крупная обезьяна семейства человекообразных отряда приматов.

Губка

морского

апельсина

Желчь
- это древнейшее морское животное, имеет шарообразное тело, слегка бугорчатую поверхность и часто яркую окраску.

- это густой секрет с щелочной реакцией, вырабатываемый печенью и накапливающийся в желчном пузыре.

Жерло вулкана - это канал, соединяющий очаг вулкана с земной поверхностью.

Земная кора - это самая верхняя из твёрдых оболочек Земли.

Инфузория- - это микроскопическое животное, туфелька напоминающее туфельку.

Kлоп - это небольшое насекомое-паразит с неприятным запахом.

Крохаль - - это водоплавающая птица семейства утиных, с длинным узким клювом.

Кучевые

облака

- это плотные, днём ярко- белые облака со значительным вертикальным развитием.

Лотос

- это травянистое растение из семейства лотосовых.

Масштаб - это отношение длины отрезка на карте или плане к его действительной длине на местности. 
Мозаичное - это тип строения глаза насекомого. Оно (фасеточное) состоит из множества крошечных «глазков» строение глаз (фасеток).

Hъю- Форест - это место, в южной части Англии, огромные участки пастбищ, вереск земли и леса.

Ондатра

- это мускусная крыса - млекопитающее отряда грызунов

Осьминог - это морское животное отряда морских моллюсков.

Перистые _ - это прозрачные облака в виде тонких белых облака нитей или пелены, не дающие тени.

Пульс - это синхронное, с сокращением сердца, периодическое расширение кровеносных сосудов, определяемых на ощупь.

Poтоны - это рыба-хищник, живёт в пресноводных водоёмах.

Саранча - - это стадное насекомое отряда прямокрылых.

Tермиты - это отряд насекомых с неполным превращением, родственных тараканам.

Тушканчик - это животное, представитель хищных сумчатых млекопитающих, отряда грызунов.

Устрицы — - это семейство морских двустворчатых моллюсков.

Уссурийский $\quad$ - это самый крупный из жуков нашей страны ycau - имеет длину около 100 мм. 
Фазан - это крупная птица из отряда куриных, с ярким оперением.

Фитонциды - это биологически активные вещества, убивающие рост и развитие бактерий.

Фрегаm - это в парусном военном флоте трёхмачтовый военный корабль.

Хвош - это род многолетних травянистых растений, с разветвлённым корневищем.

Хлопчатник - это растение, семена которого покрыты пушистыми волосками, дающими хлопок. 


\section{1 КЛАСС}

\section{Задачи на нахождение суммы}

1. Вокруг Марса вращаются 2 естественных спутника, а вокруг планеты Уран- 5 спутников. Сколько всего спутников у Марса и Урана вместе? Если знаешь, как они называются - напиши.

2. Глаз насекомого имеет мозаичное (фасеточное) строение. Он состоит из множества глазков. У мухи их 4 тысячи, а у муравья- 6 тысяч глазков. Сколькими глазами на тебя смотрят вместе муха и муравей?

3. Дикие гуси живут 80 лет, а собаки- 20 лет. Орёл живёт столько, сколько собака и гусь вместе. Сколько лет живёт орёл?

4. Сейчас охота в нашей стране запрещена полностью на18 видов зверей и 29 видов птиц. На сколько видов зверей и птиц запрещена охота?

5. На цветке сидит шмель, собирает пыльцу. К нему прилетел ещё 1 шмель. Сколько всего шмелей на цветке?

6. Белка выбирает семечки из еловой шишки. К ней на ель прыгнули ещё 2 белки. Сколько всего белок стало на ели?

7. 4 пчелы прилетели в улей с одного поля и 1 пчела - с другого. Сколько всего пчёл прилетело в улей?

8. Белка устроила гнездо в дупле. Утром она принесла в дупло 3 еловые шишки, а вечером ещё 2. Сколько шишек стало в дупле?

9. В саду посадили 3 яблони и 4 груши. Сколько всего деревьев посадили в саду?

10. Под берёзой росли 3 подберёзовика и 2 мухомора. Сколько всего грибов росло под берёзой? Сколько съедобных грибов можно сорвать? 
11. На лугу паслись 5 коров, 4 лошади, 7 овец и 2 козы. Сколько всего домашних животных паслось на лугу?

12. В парке у школы росли 10 елей, 15 берёз, 20 тополей, 3 сосны. Сколько всего деревьев росло у школы? Сколько лиственных деревьев? Сколько хвойных?

13. На ветке сидело 3 синицы, 5 воробьёв, 4 зяблика. Сколько всего птиц сидело на ветке? Сколько из них зимующих?

14. На опытной грядке росло 54 моркови, 27 луковиц, 2 лебеды, 6 одуванчиков. Сколько растений росло на грядке? Сколько из них сорные? Как называются остальные растения?

15. В корзине лежало 5 огурцов, 15 помидоров, 10 яблок, 20 слив. Сколько плодов лежало в корзине? Сколько фруктов лежало в ней? Сколько овощей лежало в корзине?

16. На дачном участке посадили 2 яблони, 3 сливы, 4 куста смородины, 5 кустов крыжовника, 20 тюльпанов, 30 гвоздик. Сколько всего растений посадили на участке? Сколько деревьев посадили? Сколько кустарников посадили на участке? Сколько трав посадили на участке?

17. Каждый океан содержит в себе несколько морей. Подсчитайте сколько всего морей содержат все океаны Земли, если: в Тихом океане 9 морей, в Атлантическом- 6 морей, в Индийском- 5 морей и в Северном Ледовитом-10 морей.

18. У кормушки сидело 3 синицы, 3 воробья, 5 снегирей .Сколько птиц сидело у кормушки? Какие из них прилетают к нам на зиму? Сколько птиц зимуют у нас?

\section{Задачи на увеличение и уменьшение числа} на несколько единиц

19. В Тихом океане 9 морей, а в Атлантическом на 3 моря меньше. Сколько морей в Атлантическом океане? 
20. На планете Сатурн сутки длятся 10 часов, а на планете Уран на 7 часов больше. Сколько часов длятся сутки на планете Уран?

21. Кучевые облака образуются на высоте 10 км, а перистые на 2 км выше. На какой высоте образуются перистые облака?

22. Крокодильчики появляются на свет из яиц. Если яйцо прогреется до 30 градусов- то вылупится девочка, а если температура поднимется ещё на 2 градуса - то вылупится мальчик. При какой температуре вылупляются мальчикикрокодильчики?

23. Семена тыквы сохраняют всхожесть 8 лет, а пшеницы на 8 лет больше. Сколько лет семена пшеницы сохраняют всхожесть?

24. В редком лесу ели цветут на 15 -ый год, а в густом лесу на 15 лет позже. Во сколько лет цветут ели в густом лесу?

25. Частота дыхания в минуту у человека равна 17 раз, у кролика на 7 раз чаще, чем у человека, а у лошади на 4 раза меньше, чем у кролика. Сколько раз в минуту дышит лошадь?

26. Рабочая пчела выходит из ячейки через 21 день, матка на 4 дня раньше, а трутень на 7 дней позже матки. Через сколько дней выходит из ячейки трутень?

27. Скворец живёт 20 лет, иволга на 2 года дольше, чем скворец, а сорока на 10 лет больше, чем скворец и иволга вместе. Сколько лет живёт жаворонок?

28. Ласточка живёт 16 лет, оляпка на 8 лет меньше, а жаворонок на 1 год дольше, чем оляпка. Сколько лет живёт жаворонок?

29. Протяженность государства Сингапур с севера на юг составляет 23 км, а с запада на восток на 19 км больше. Какова протяжённость Сингапура с запада на восток?

30. У рака 10 ног, а у пчёлки на 4 меньше. Сколько ног у пчёлки?

31. У сосны хвоинки живут 2 года, а у ели на 10 лет больше. Сколько лет живут хвоинки у ели?

32. У паука 8 ног, а у рака на 2 больше. Сколько ног у рака? 
33. У взрослого человека 5 л крови, а у ребёнка на 2 л меньше. Сколько литров крови у ребёнка?

34. Количество детёнышей в приплоде у медведя на 2 меньше, чем у белки, а у белки на 4 меньше, чем у кролика. На сколько детёнышей меньше в приплоде у медведя, чем в приплоде у кролика?

35. На болоте в камышах стоят 5 цапель. 1 цапля улетела на другое болото. Сколько цапель осталось на болоте в камышах?

36. На кустике земляники висело 5 ягод. 2 ягоды созрели и их сорвали. Сколько ягод осталось на кустике?

37. На кусте расцвело 6 роз. 3 розы мальчик подарил маме, а остальные бабушке. Сколько роз он подарил бабушке?

38. На клумбе утром распустилось 8 астр, а к вечеру их стало на 2 больше. Сколько всего астр распустилось к вечеру?

39. 7 гусениц завились в кокон и стали куколками. Через несколько дней 2 куколки превратились в бабочек. Сколько бабочек ещё должно появиться?

40. Ребята посадили около школы 7 кустов сирени, а шиповника на 3 куста больше. Сколько кустов шиповника посадили ребята?

41. Высота рябины 6м, а тополь на 3 м выше рябины. Найди высоту тополя.

42. Ворон живёт около 75 лет, слон на5 лет меньше, а щука на 5 лет меньше, чем слон. Сколько лет живёт щука?

\section{Задачи на нахождение неизвестного вычитаемого, слагаемого, уменьшаемого}

43. На стебле было 4 колокольчика. Подул ветер. Остался 1 колокольчик. Сколько колокольчиков опало? 
44. 5 лисят спасаются от охотника. Несколько лисят спрятались в норе, а 3 не успели. Сколько лисят спрятались в норе?

45. На поляне росло 3 липы и несколько берёз. Всего 7 деревьев. Сколько берёз росло на поляне?

46. У лебедя на всём теле около 25 тысяч перьев. Из них на голове и шее 20 тысяч перьев. Сколько перьев на остальном туловище лебедя?

47. В течение жизни человек спит 25 лет. 5 лет из них видит сны. Сколько лет в течение жизни человек спит и не видит снов?

48. Австралия омывается 4 морями. Из них 2 морями на востоке, а остальными на севере. Сколько морей омывает Австралию с северной стороны?

49. У цветка трёхцветной фиалки 5 лепестков: 1 белый, голубых на 1 больше, а остальные фиолетовые. Сколько фиолетовых лепестков у этой фиалки?

50. В России в середине апреля зацветает мать-и-мачеха, через 5 дней зацветает орешник, через 6 дней после зацветания орешника, 24 апреля, цветёт красная верба. Какого числа появятся цветы у мать-и-мачехи?

51. Срок жизни наших далёких предков первобытных людей был 20 лет. На сколько лет он увеличился в наше время, если сейчас средняя продолжительность жизни человека составляет 70 лет?

52. В Россию в начале марта прилетают грачи, через 16 дней прилетают жаворонки, а через 2 дня после этого, 30 марта, прилетают скворцы. Когда прилетают к нам грачи?

53. Американские учёные установили, что из каждых 100 свиней 50 вращают хвостом по часовой стрелке, против - на 32 меньше, а остальные - в обе стороны. Сколько свиней вращают хвостом в обе стороны? 
54. Летучие мыши перед стартом издают несколько звуковых сигналов в секунду, а в полёте на 20 больше, а с приближением к препятствию на 30 сигналов больше, чем в полёте, что составляет 60 сигналов. Сколько звуковых сигналов в секунду издаёт летучая мышь перед стартом?

55. В России в первой половине июня зацветает малина, через 2 дня цветёт калина, а через 15 дней после цветения калины, 29 июня, зацветает зверобой. Какого числа начнёт цвести малина?

\section{Задачи на разностное сравнение}

56. 22 декабря на юге нашей страны самая длинная ночь 17 часов, а день длится всего 7 часов. На сколько часов ночь длиннее дня?

57. Летом, 22 июня, на юге нашей страны самый длинный день 18 часов, а ночь продолжается всего 6 часов. На сколько часов день длиннее ночи?

58. В 100 граммах тыквы 91 грамм воды, а в 100 граммах помидоров 93 грамма воды. На сколько меньше воды в 100 граммах тыквы, чем в 100 граммах помидоров?

59. В 100 граммах яблок 84 грамма воды, а в 100 граммах моркови87 граммов воды. На сколько больше граммов воды в 100 граммах моркови, чем в 100 граммах яблок?

60. Утка может прожить 15 лет, а гусь - 18 лет. На сколько гусь живёт дольше утки?

61. Корова может прожить 20 лет, а свинья 15 лет. На сколько лет свинья живёт меньше коровы?

62. У собаки 42 зуба, а кошки 30 зубов. На сколько зубов больше у собаки, чем у кошки?

63. Овца живёт 15 лет, что на5 лет дольше, чем заяц. Сколько лет живёт заяц?

64. Можжевельник в сутки выделяет 30 кг ароматных веществ, 
убивающих бактерии (фитонцидов), а берёза -2 кг. На сколько больше килограммов ароматных веществ, убивающих фитонцидов, выделяет можжевельник, чем берёза?

65. У сумчатых мышей в Австралии 8 зубов в верхней челюсти, что на 2 зуба больше, чем в нижней челюсти. Сколько всего зубов у сумчатой мыши?

66. У обезьян «кахау» очень длинные носы. У одной такой обезьяны длина носа составляет 14 см, что на 3 см меньше, чем у другой. Какова длина носа второй обезьяны?

67. На Земле обитают 5 видов носорогов, что на 3 вида меньше, чем видов диких свиней. Сколько видов диких свиней обитает на Земле?

68. В Азии обитают 49 видов ядовитых змей, что на 3 вида меньше, чем в Африке. Сколько видов ядовитых змей обитают в Африке?Жук-олень имеет длину 7 см, что на 4 см меньше длины уссурийского усача. Какова длина уссурийского усача?

69. Толщина земной коры под сушей 40 км, что на 34 км больше, чем под морем. Какова толщина земной коры под морем?

\section{Задачи на нахождение суммы и остатка}

70. Раньше в Африке обитало 4 вида зебр. Охотниками был истреблён 1 вид этих животных. Сколько видов зебр осталось в Африке?

71. В Москве много рек. Из них 20 протекают на поверхности, столько же частично заключено в трубы. А целиком заключено рек в трубы на 20 больше, чем течёт на поверхности. Сколько всего рек в Москве?

72. В 100 граммах капусты содержится 90 граммов воды. Сколько граммов остальных веществ находится в 100 граммах капусты?

73. Река Авиар в Греции- удивительная река. 6 часов она течёт к 
морю и столько же часов от него. Сколько часов река Авиар течёт от моря?

74. В Америке живут 7 видов древесных крыс. Из них 4 вида питаются листьями и плодами кактусов, а остальные- другими растениями. Сколько видов древесных крыс питаются другими растениями?

75. В 100 граммах свёклы содержится 86 граммов воды. Сколько остальных веществ содержится в 100 граммах свёклы?

76. Кедровая шишка с семенами созревает 2 года 3 месяца. Сколько это месяцев?

77. В Москве обитают 30 видов стрекоз, а шмелей на 14 видов меньше. Сколько всего видов стрекоз и шмелей обитают в Москве?

78. Небольшой хвойный лес отфильтровывает за год 35 тонн пыли, а такой же лиственный на 35 тонн больше. Сколько тонн пыли отфильтровывает лиственный лес? Лиственный и хвойный лес вместе?

79. Один гектар хвойного леса выделяет за сутки 5 кг фитонцидов, а лиственного леса на 2 кг меньше, а можжевелового на 23 кг больше, чем 1 гектар хвойного и лиственного лесов вместе. Сколько килограммов фитонцидов выделяет 1 гектар лиственного леса, 1 гектар хвойного и 1 гектар можжевелового леса вместе?

80. Ондатра может находиться под водой 12 минут, что на 6 минут меньше, чем серый тюлень. Сколько минут под водой может находиться серый тюлень?

81. Утконос может находиться под водой 12 минут, что на 3 минуты меньше, чем утка. Сколько минут под водой может находиться утка? 


\section{Задачи на закрепление пройденного материала}

82. За последние 300 лет исчезли 36 видов млекопитающих, а птиц на 58 видов больше. Сколько всего видов птиц и млекопитающих лишилась планета Земля? Если знаешь, назови некоторых?

83. Слон дышит с частотой 6 раз в минуту, а собака на 15 раз больше. С какой частотой дышит собака?

84. В Красную книгу занесены 19 из 21 видов крокодилов. На сколько видов крокодилов меньше занесено в Красную книгу, чем всего видов?

85. У бегемота нижние клыки достигают длины 50 см. Сколько это дециметров?

86. Длина варана с хвостом 150 см. Длина его тела 50 см. На сколько сантиметров тело варана короче его хвоста?

87. В группе горилл 20 обезьян. Из них 1 вожак, самок на 5 больше, молодых горилл на 4 меньше, чем самок, а остальные детёныши. Сколько детёнышей в этой группе?

88. На Земле обитают 62 вида буревестников, а альбатросов на 50 видов меньше. Сколько всего видов буревестников и альбатросов обитают на Земле?

89. Длиннохвостые обезьяны прыгают на 10 метров, что на 2 метра дальше, чем гепарды. Сколько метров составляет прыжок гепарда?

90. Самое «замёрзшее» озеро Таймыр. 10 месяцев в году его сковывает двухметровый лёд. Сколько месяцев в году обитатели озера видят Солнце?

91. Пульс человека 60 ударов в минуту, а лягушки на 30 ударов в минуту меньше. Какой пульс у лягушки?

92. Семена гороха сохраняют жизнеспособность 30 лет, а семена лотоса на 70 лет больше. Сколько лет сохраняют жизнеспособность семена лотоса? 


\section{2 КЛАСС}

\section{Простые задачи на умножение}

1. У гремучей змеи в трещотке на хвосте 8 погремков. Сколько погремков у 3 гремучих змей?

2. Во рту у слона 4 зуба. Сколько зубов у 5 слонов?

3. У рыбки колюшки на спинном плавнике 9 шипов. Сколько шипов у 6 рыбок колюшек?

4. У рыбки морского драконника на спинном плавнике 7 шипов. Сколько шипов у 8 морских дракончиков?

5. В каждом взрослом человеке обитает примерно 7 кг бактерий. Сколько килограммов бактерий у 8 человек?

6. Луна удаляется от Земли каждый год на расстояние 4 см. На сколько сантиметров удалится Луна от Земли за 5 лет?

7. В одном стручке 6 горошин. Сколько горошин в 5 таких же стручках?

8. Корове в сутки необходимо 9 кг сена. Сколько килограммов сена нужно корове на 9 дней?

9. Овца даёт 10кг шерсти в год. Сколько килограммов шерсти даст овца за 4 года?

10. Бамбук вырастает за сутки на 1м. На сколько метров вырастет бамбук за 7 суток?

11. Чтобы собрать 1 кг мёда, пчела должна преодолеть путь равный длине экватора. Сколько мёда соберут 5 пчёл, если каждая сделает над экватором 5 кругов?

Задачи на увеличение и уменьшение числа в несколько раз

12. В Северном Ледовитом океане 10 морей, а в Индийском в 2 раза меньше. Сколько морей в Индийском океане? 
13. Страус делает 3 вздоха в минуту, а лисица в 8 раз больше. Сколько вздохов в минуту делает лисица?

14. Масса сердца фазана 6 граммов, а чайки в 3 раза меньше. Какова масса сердца чайки?

15. Саранча прыгает в 28 раз длиннее своего тела, а прыгучесть кенгуру в 4 раза меньше прыгучести саранчи. Во сколько раз больше своего тела прыгает кенгуру?

16. Масса сердца питона 6 граммов, а удава в 3 раза больше. Какова масса сердца удава?

17. Аист делает 8 вздохов в минуту, а ворона в 3 раза больше. Сколько вздохов в минуту делает ворона?

18. Из 90 кг хлопка получается в 2 раза меньше ваты. Сколько получается ваты из 90 кг хлопка?

19. В огороде 8 грядок с луком, а с картофелем в 3 раза больше. Сколько в огороде грядок с картофелем?

20. Ласточка - касатка летает со скоростью 28км/ч, а стриж в 4 раза быстрее. С какой скоростью летает стриж?

21. Масса ведра с солью 27кг, а со снегом в 9 раз меньше. Какова масса ведра со снегом?

22. Морская звезда живёт 5 лет, что в 4 раза меньше, чем паук. Сколько лет живёт паук?

23. Вместимость желудка овцы составляет 14 литров, что в 7 раз больше, чем у собаки. Какова вместимость желудка собаки?

24. Длина новорождённого крокодильчика 30 см, что в 3 раза больше длины яйца, из которого он вылупился. Какова длина этого яйца?

25. Средняя длина голубой акулы 3 м, это в 2 раза меньше её максимальной длины. Какова максимальная длина голубой акулы?

26. Длина карманного краба 20 см, а травяного 5см. Во сколько раз меньше длина травяного краба? 
27. Червь-пескожил ест 3 часов в сутки, что в 2 раза меньше, чем тогда, когда он не питается. Сколько часов в сутки червьпескожил не принимает пищу?

28. У паука 2 основных глаза, а побочных в 3 раза больше. Сколько всего глаз у паука?

29. Масса сердца белки 3 грамма, это в 3 раза больше массы сердца крысы, а масса сердца морской свинки такая, как белки и крысы вместе. Какова масса сердца морской свинки?

30. Плод кокосовой пальмы весит 2 кг, а сейшельской в 12 раз больше. Сколько килограммов весят 2 ореха сейшельской пальмы вместе?

31. Летучая мышь делает 50 вздохов в минуту, а лошадь в 5 раз меньше. Сколько вздохов в минуту делают вместе летучая мышь и лошадь?

32. Антарктиду омывают воды 3 океанов, а морей в 2 раза больше. Сколько всего океанов и морей омывают Антарктиду?

\section{Задачи на деление по содержанию и на равные части}

33. 33.Одни сутки на планете Меркурий длятся 2 его года. Сколько суток пройдёт на этой планете за 10 лет?

34. Ящерицы медянки залегают в спячку по 20 штук. Сколько групп составят 80 ящериц медянок?

35. Страусы живут группами по 30 штук. Сколько групп составят 90 страусов?

36. Длина шага страуса при беге достигает 6м. Сколько шагов он сделает, преодолев расстояние в 42 метра?

37. Мозг кита состоит из двух половинок. Когда кит спит, половинки его мозга работают по очереди: пока одна спит другая работает. Сколько времени проработало каждое полушарие мозга за 12 минут? За 18 минут? 
38. У пыльцы сосны по бокам 2 «воздушных шара», которые помогают ей перелетать. У скольких штук пыльцы можно увидеть 14 «воздушных шаров»?

39. Киты каждые 4 минуты всплывают к поверхности, чтобы дышать. Сколько раз всплывает кит за 28 минут?

40. Для естественного восстановления слоя почвы толщиной в 1 см требуется примерно 100 лет. Из-за роста оврагов с поля смыло в половодье 10 см почвы. Сколько лет потребуется для восстановления этого слоя?

41. В квартире подтекает водопроводный кран. За 6 минут набегает полный стакан воды. Сколько воды вытекает из неисправного крана за 1 час? А за 1 сутки?

42. Самая долгая радуга была видна в течение 180 минут. Сколько часов продолжалось это событие?

\section{Простые и составные задачи на кратное и разностное сравнение}

43. Сутки на планете Юпитер длятся 9 часов, а на планете Нептун 18 часов. Во сколько раз дольше длятся сутки на планете Нептун?

44. Из 60 кг семян хлопчатника отжимают 15 кг масла. Во сколько раз больше берут хлопчатника, чем получают масла?

45. Масса ведра с солью 27 кг, а ведра со снегом - 3 кг. Во сколько раз ведро с солью тяжелее ведра со снегом?

46. Высота можжевельника 10 м, а сосны - 40м. Во сколько раз можжевельник ниже сосны?

47. Сутки на планете Нептун длятся 18часов, а на планете Плутон 6 часов. Во сколько раз короче сутки на планете Плутон? 
48. Длина ползущих побегов растения душицы в возрасте 1 года составляет 5 см, а хвоща 15 см. Во сколько раз длиннее побеги хвоща?

49. Растение валериана цветёт 2 месяца, а василёк 4 месяца. Во сколько раз дольше валерианы цветёт василёк?

50. Бодрствующий ёж делает 20 вздохов в минуту, а находящийся в зимней спячке 5 раз в минуту. Во сколько раз чаще дышит бодрствующий ёж?

51. Длительность цветения одного цветка золототысячника составляет 6 дней, а клюквы 18 дней. Во сколько раз дольше цветёт клюква?

52. Длина сердца у взрослого человека 12 см, а ребёнка до года 3 см. Во сколько раз длина сердца взрослого человека больше длины сердца годовалого ребёнка?

53. Муравьиная царица может дожить до 21 года, а рабочий муравей живёт на 14 лет меньше. Во сколько раз дольше живёт муравьиная царица?

54. Длительность цветения одного цветка шафрана составляет 12 дней, а жимолости на 9 дней меньше. Во сколько раз дольше цветёт шафран?

55. Антарктиду омывают воды 3 океанов, а морей в 2 раза больше. На сколько меньше океанов, чем морей, омывают Антарктиду?

56. У первых на Земле крылатых стрекоз размах крыльев достигал 90 см, а у ныне обитающих на 73 см меньше. Во сколько раз больше размах крыльев был у первых стрекоз, чем у ныне обитающих?

57. У планеты Уран 5 спутников, а у Нептуна на 3 спутника меньше, чем у Урана, а у Сатурна в 8 раз больше спутников, чем у Нептуна. На сколько меньше спутников у Урана и Нептуна вместе, чем у Сатурна? 


\section{Задачи на приведение к единицы и на нахождение суммы двух}

\section{произведений}

58. У 5 раков 50 ног. У скольких раков 70 ног?

59. У гремучих змей на хвосте 32 погремка. У скольких змей 56 погремков?

60. У 9 пауков 72 ноги. У скольких пауков можно увидеть 32 ноги?

61. У 3 осьминогов 9 сердец. У скольких осьминогов 18 сердец?

62. У 3 жирафов 12 рогов. У скольких жирафов того же вида 20 рогов?

63. На далёком южном острове Суматре растёт самый тяжёлый цветок на свете. Его вес 6 кг. Сколько килограммов будут весить два букета из этих цветов, если в одном букете 3 цветка, а в другом 7 цветков?

64. Клопы откладывают яйца на растения характерными кладками в 2 ряда по 6 яиц. Сколько яиц отложат 3 клопа?

65. За сутки кожа человека выделяет 600 граммов воды, а лёгкие в 2 раза меньше. Сколько всего граммов воды выделяют кожа и лёгкие?

66. У 3 рыбок бычков и 2 ставрид в спинных плавниках 35 шипов. По сколько шипов у каждой рыбки?

67. У 4 скумбрий и 5 ротанов в спинных плавниках 72 шипа. По сколько плавников у каждой рыбки?

68. У 4 карасей и 2 горбылей в спинных плавниках 60 шипов. По сколько плавников у каждой рыбки?

\section{Задачи на нахождение уменьшаемого, вычитаемого,} разности и на нахождение неизвестного слагаемого

69. Тополь поглощает в месяц 9кг углекислого газа. Во дворе растут 4 тополя. Сколько должно быть ещё деревьев во дворе, чтобы они поглощали 81кг углекислого газа в месяц? 
70. В гнёздах гаг после выведения птенцов остаётся по 100 граммов пуха. Сборщик взял 70 граммов пуха. Сколько пуха осталось ещё в гнездах

71. Листочек хищного растения росянки съедает 3 насекомых и засыхает. Под растением лежало 6 засохших листочков. Сколько насекомых съела росянка?

72. Тушканчик прыгает на 3 м за 1 прыжок. От холмика, где стоял тушканчик, до норки 24 м. После того как его спугнули, он сделал несколько прыжков и остановился за 2 прыжка до норки. Сколько прыжков сделал тушканчик?

73. В 100 граммах яйца содержится 72 грамма воды, а жиров в 8 раз меньше. Сколько остальных веществ содержится в 100 граммах яйца?

74. Пустыня Сахара расширилась за 5 лет на 30 км. В первый год она увеличилась на 10 км. По сколько километров увеличивалась пустыня Сахара в остальные годы?

75. Скворчата не умеют очищать пёрышки от клещей. Для защиты птенцов скворцы принесли 3 веточки мяты по 5 листочков на каждой и несколько веточек с 6 листочками. Сколько было веточек с 6-ю листочками, если общее количество листьев составило 27 штук?

76. Жабы приносят большую пользу. Учёные подсчитали, что ежегодная прибыль фермерскому хозяйству от жабы составляет 30 долларов. Сколько прибыли принесут 3 жабы, живущие на ферме?

77. Корень растения женьшень очень целебный и дорогой. Корень массой 600 г был продан на ярмарке во Владивостоке за 1800 долларов. Сколько стоит каждый грамм этого корня?

78. С одного улья собрали 40 кг мёда, а с другого - на 12кг больше. Сколько всего мёда собрали с двух ульев?

79. Ребята посадили в парке 70 деревьев. Из них 30 лип, 23 берёзы, а остальные клёны. Сколько клёнов посадили ребята? 
80. На поляне росло 25 сыроежек и 10 волнушек. После дождя появилось ещё 20 грибов. Сколько грибов стало на поляне?

81. На одном кусте орешника созрело 35 кг орехов, а на другом 32 кг. 15 кг собрали белки для запасов на зиму. Сколько килограммов орехов осталось на двух кустах?

82. За лето школьники собрали 28 кг шиповника, а черники на 5 кг меньше. Сколько всего ягод собрали школьники?

83. Высота кедра 45 м, а берёзы на 20 м ниже, чем кедра, а дуба на 13 м выше, чем берёзы. Какова высота дуба?

84. Для предупреждения размыва оврага по одному склону посадили 27 кустарников, а по другому склону на 7 кустарников больше. Сколько кустарников посадили по обоим склонам оврага?

85. Астры по высоте делятся на три группы: высокие -100 см, средние - на 40 см ниже, чем высокие, и низкие - в 3 раза короче, чем средние. Найди высоту низких астр.

86. Журавль живёт на 10 лет меньше филина, а филин на 40 лет дольше скворца. На сколько лет продолжительность жизни журавля больше, чем скворца?

87. При рождении скелет ребёнка имеет 350 костей, у взрослого человека- 260 костей. На сколько костей в скелете взрослого человека меньше, чем у новорождённого?

88. Позвоночник состоит из 33 позвонков, из них 7 шейных, грудных - на 5 больше, поясничных и крестцовых- поровну, копчиковых- в 3 раза меньше, чем грудных. Сколько у человека грудных позвонков, копчиковых позвонков, поясничных, крестцовых позвонков?

\section{Задачи на нахождение числа по доле и доли по числу}

89. В Тихом океане 9 морей, а в Атлантическом на 1/3 меньше. Сколько морей в Атлантическом океане?

90. Длина ног взрослого человека составляет половину его 
роста. Найди рост человека, у которого длина ног составляет 80 см?

91. Всего в мире растёт 50 видов земляники, а в России десятая часть. Сколько видов земляники растёт в России?

92. В России растёт 6 видов елей. Это шестая часть всех видов, которые растут в мире. Сколько всего существует видов елей?

93. Лето длится четвертую часть года. Сколько это месяцев?

94. Кости, входящие в состав скелета, составляют пятую часть общей массы тела. Найди массу своего скелета.

95. Всего в мире растёт 50 видов крапивы, а в России пятую часть. Сколько видов крапивы растёт в России?

96. Длина хвои кедровой сосны 5см. Это третья часть длины хвои пицундской сосны. Найди длину хвои пицундской сосны.

97. Длина прыжка обезьяны гиббона 12м. А длина его тела составляет половину длины его прыжка. Какова длина тела гиббона?

98. Земная кора содержит четверть всей воды Земли, а остальная вода содержится в морях и океанах. Сколько частей воды содержится в морях и океанах?

99. Толщина баобаба составляет пятую часть его высоты. Найди высоту баобаба, толщина которого 6 м. 


\section{3 КЛАСС}

\section{Задачи на движение}

1. Лошадь идёт шагом со скоростью 5 км/ч, а галопом в 3 раза быстрее, чем шагом, а рысцой на 8 км медленнее, чем галопом. С какой скоростью бежит лошадь рысцой?

2. Некоторые ледники в процессе своего движения время от времени делают стремительные «рывки», при которых могут за 4 дня преодолеть расстояние равное 480 м. Чему равна их скорость?

3. Зафиксирован случай, когда стая саранчи пролетела 1000км из Марокко в Португалию со скоростью 40 км/ч. Сколько времени летела стая?

4. Большинство ледников сползают по горным склонам со скоростью 30 см в сутки. За какое время ледник проползёт $3 \mathrm{м}$ ?

5. Вращающиеся вокруг Сатурна кольца за 5 сек перемещаются на 50 км. С какой скоростью вращаются кольца вокруг Сатурна?

6. Ледник Кварайя в Гренландии сползает со скоростью 24 м в сутки. Какое расстояние преодолеет ледник за неделю?

7. На дне озера ил накапливается со скоростью 2 мм в год. За сколько лет толщина ила увеличится на 1 см?

8. Сокол-сапсан может летать со скоростью 4 км/мин. За сколько времени он пролетит 8 км?

9. Расстояние между Гавайскими островами и Японией уменьшается на 1 см в год. За какое время расстояние уменьшится на 1 дм?

10. Жук-плавунец плывёт со скоростью 30 м/мин. Какое расстояние он проплыл за 3 мин? 
11. Аральское море высыхает. Вода отступила от прибрежных посёлков за 30 лет на 69 км. С какой скоростью отступает вода?

12. Рак ползёт со скоростью 18 м/мин. Сколько времени ему потребуется чтобы преодолеть расстояние в 54 км?

13. Аист может пролететь 256 км за 16 ч. Сколько километров аист пролетит за сутки?

14. Тело инфузории- туфельки состоит из одной клетки. Она за 15 секунд перемещается на 75 мм. На сколько инфузориятуфелька переместится за 1 ч, если её скорость уменьшится на $6 \mathrm{~cm} /$ мин?

15. Лава, вырвавшаяся из жерла вулкана, 2 часа текла к океану со скоростью 32 км/ч. После этого ей осталось преодолеть расстояние в 2 раза больше. Чему равно расстояние между жерлом вулкана и океаном?

16. Стрекоза пролетела расстояние между Жигулёвским и Самарой, равное 100 км, со скоростью 25 км/ч. Пчела потратила на эту дистанцию на 1 час больше. С какой скоростью летела пчела?

17. Космонавт в невесомости оттолкнул от себя мяч. Мяч полетел со скоростью 6 м/сек, а космонавт в противоположном направлении со скоростью 10 см/сек. На каком расстоянии они окажутся через 5 секунд?

18. Скорость приливного течения у побережья Англии 60 м/мин. Сколько это в м/ч?

19. Уж ползёт со скоростью 33 м/мин. Сколько в см/сек проползает уж?

20. Краб ползёт со скоростью 57 м/мин. Сколько см/сек проползёт краб?

21. Шмель летит со скоростью 18 км/ч. Сколько м/ сек пролетает шмель?

22. Пингвин при нырянии может развить скорость 32 км/ч. Сколько это в м/ч? 
23. Земля движется вокруг Солнца со скоростью 30 км/сек. Сколько км/ч пролетает Земля?

24. Гончая собака бежит со скоростью 30 м/сек. Сколько м/мин пробегает гончая собака?

25. Расплавленная лава из жерла вулкана стекает по склону со скоростью 125 дм/сек. Сколько это в м/мин?

26. Гремучая змея ползёт со скоростью 60 м/мин. Сколько м/сек проползёт гремучая змея?

27. Дельфин плывёт со скоростью 12 м/сек. Сколько м/мин проплывёт дельфин?

28. Скорость ветра при урагане достигает 36 м/сек. Сколько это м/ч?

29. Крохаль летит со скоростью 35 м/сек. Сколько м/мин пролетает крохаль?

30. Эскимосская собака бежит со скоростью5 м/сек. Сколько м/мин пробегает эскимосская собака?

31. Страус бежит со скоростью 20 м/сек. Сколько км/ч пробегает страус?

32. Два гепарда бежали с одинаковой скоростью. Один пробежал 100км, другой-200км. Второй гепард был в пути на 2ч меньше. Сколько часов был в пути каждый гепард?

33. Из зоопарка убежал сайгак. Животное очень редкое, на воле оно могло погибнуть в непривычных условиях. Сайгака поймали через 3 ч за 180 км от зоопарка. С какой скоростью бежал сайгак?

34. $3 \mathrm{a} 3$ дня верблюд прошёл 240 км. С какой скоростью шёл верблюд?

35. Первые 20 минут меч-рыба плыла со скоростью $120 \kappa$ м/ч, а затем ещё 10 минут со скоростью 90 км/ч. Сколько километров проплыла рыба?

36. Ёж, когда ему угрожает опасность, пробегает в секунду 2 м. Это в 2 раза медленнее, чем пробегает заяц. Сколько метров пробегает заяц за 15 секунд? 


\section{Задачи на пропорциональное деление}

\section{и нахождение числа по доле и доли по числу}

37. В шести вольерах зоопарка 12 пони Эксмур и 6 - НьюФорест. Сколько вольеров с пони Эксмур и сколько с НьюФорест?

38. Две одинаковые гигантские устрицы отфильтровали 140 л воды. Одна трудилась 2ч, а другая-5ч. Сколько литров воды отфильтровала каждая устрица?

39. Одно из самых высоких деревьев на Земле, вечнозелёная секвойя, растёт в Калифорнии (США) и достигает высоты 100 м. Баобаб, дерево-богатырь африканских саванн, по высоте в 4 раза ниже секвойи. Какова высота баобаба?

40. Чтобы заполнить чашу Байкала, все реки мира должны были бы в течение 2/3 года отдавать свои воды. Сколько это месяцев?

41. Ширина губки морского апельсина 9см. Если по ней щёлкнуть, то она потеряет $2 / 3$ своей ширины. Какой ширины она тогда станет?

42. Под $3 / 5$ общей площади Польши находятся залежи соли. Под какой частью Польши нет солевых залежей?

43. Внутри ореха (плода) веерной пальмы, массой 25 кг, находится семя, масса которого составляет 4/5 массы плода. Найдите массу этого самого крупного на свете семени.

44. Длина головы гренландского кита составляет $1 / 3$ часть всей его длины. Определите длину головы кита, если вся его длина достигает $21 \mathrm{~m}$.

45. В лесах обитает $2 / 3$ всех видов растений и животных. Какая часть растений и животных обитает в других местах?

46. Длина кишечника лошади 20 м, что составляет $1 / 10$ часть длины кишечника синего кита. Чему равна длина кишечника синего кита? 
47. Очищенные от косточек вишни теряют во время сушки 7/8 своей массы. Сколько получится сухих вишен из 2 .свежих?

48. Длина кишечника волка 6м, что составляет $1 / 7$ часть длины кишечника верблюда. Чему равна длина кишечника верблюда?

49. Продолжительность зимней спячки травяной лягушки 4 месяца. Какую часть года спит лягушка?

50. Когдачеловеку холодно - он начинает дрожать. При этом он согревается, потому что $1 / 5$ часть энергии тратится на механическую работу, а вся остальная энергия превращается в тепло. Какая это часть энергии?

51. Каждый год сосна сбрасывает 1/3 часть хвои, которая потом вырастает. Какую часть хвои сосна не сбрасывает?

52. В природе насчитывается 96 различных видов грибов. Из них 2/3 части составляют грибы, которые можно увидеть только под микроскопом. Сколько существует видов других грибов?

53. Надводная часть айсберга имеет высоту $21 \mathrm{~m}$, что составляет 1/7 часть всего айсберга. Найдите длину подводной части айсберга.

54. В водах океана в среднем на 1000 г воды приходится 35 г соли. В Азовском море солёность воды составляет 2/5 океанской. В Чёрном море в 1 кг воды соли на 4 г больше. Определите, сколько граммов соли в 1 кг черноморской воды.

55. Картофель, сваренный в кожуре, сохраняет 75\% витаминов. Картофель, очищенный и сваренный целыми клубнями $60 \%$, а порезанный кусками - 35\%. Во сколько раз больше витаминов сохраняется в картофеле, сваренном в кожуре, по сравнению с картофелем, очищенным и порезанным кусками? 


\section{4 КЛАСС}

\section{Простые задачи с многозначными числами}

1. Каштан очищает городской воздух от выхлопных газов. В Москве растёт 10 тысяч каштанов, а в Киеве в 5 раз больше. Сколько каштанов растёт в Киеве?

2. Гусеница может съесть 30 листьев за сутки. Сколько листьев могут съесть 10 гусениц, 100 гусениц за это же время?

3. В 1984 году в нашей стране было 143 заповедника. За последние годы создано ещё 50 новых заповедников. Сколько заповедников стало в нашей стране?

4. Один гектар леса выделяет ежегодно 28 т кислорода, а вырубается каждый год 12 млн. га леса. Сколько тонн кислорода недополучает Земля в год?

5. Клён выделяет в год 2 кг 100 г кислорода, а вяз в 7 раз больше, чем клён. Сколько кислорода в год выделяет вяз?

6. Липа живёт 500 лет, а дуб 2000 лет. Во сколько раз меньше живёт липа, чем дуб? На сколько лет меньше живёт липа, чем дуб?

7. За последние годы урожайность съедобных грибов с 1 га снизилась с 202 кг до 101 кг. Во сколько раз снизилась урожайность грибов с 1 га?

8. В среднем по величине в муравейнике живёт до 300000 муравьёв, а в термитнике - 600000 термитов. Во сколько раз в своих жилищах живёт больше термитов, чем Муравьёв?

9. Каждый житель Земли расходует в год количество бумаги, которое получается из трёх хвойных деревьев. Сколько хвойных деревьев в год требуется на вашу семью?

10. Из 250 тысяч видов растений Земли $1 / 10$ часть находится в угрожающем положении. Сколько видов растений на Земле на грани исчезновения? 
11. Один вяз за сезон (с мая по сентябрь) усваивает из воздуха 120 г сернистого газа, самого распространённого и ядовитого загрязнителя природы. Вяз живёт 400 лет. Сколько сернистого газа уничтожает вяз за свою жизнь?

12. Дубовая роща выделяет в год 830 кг кислорода, а такая же сосновая роща - 540 кг. На сколько килограммов больше кислорода выделяет дубовая роща, чем сосновая?

13. Опал - загадочный камень. Скорость его роста 1 см за 200000 лет. За какое время камень вырастет на 20 мм?

14. Во время солнечного затмения тень Луны движется по поверхности Земли со скоростью 3600 км/ч. Сколько м/сек пробегает тень?

15. Во время взрыва сверхновой звезды вещество этой звезды выбрасывается в космос со скоростью 72000000 км/ч. Какова его скорость в км/сек?

16. Во время землетрясения в океане возникла гигантская волна - цунами. Она распространилась со скоростью до 900 км/ч. Сколько она проходила дм/сек?

17. Солнечная система - это Солнце и его все планеты движется вокруг центра галактики со скоростью 900000 км/ч. Какова скорость движения Солнечной системы в м/мин?

18. В каком веке могла родиться встреченная тобой черепаха, если продолжительность её жизни 150 лет?

\section{Составные задачи с многозначными числами}

19. Берёза в сутки поглощает из почвы 40 л влаги, а эвкалипт в 8 раз больше. Сколько влаги из почвы поглощают в сутки берёза и эвкалипт?

20. Ежегодно в нашей стране собирают 11 млн. тонн ягод, 5 млн. тонн орехов, 330 тыс. тонн грибов. Сколько всего природных даров собирают в нашей стране? 
21. Богомол (насекомое, похожее на кузнечика) съедает за месяц 42 тли, плодовых мушек в 3 раза меньше, чем тлей, а комнатных мух в 6 раз больше, чем плодовых. Сколько всего насекомых поедает богомол за 1 месяц? А за 3 летних месяца?

22. Ласточка за 5 суток может пролететь 3000 км. Сколько километров может пролететь она за 8 суток, если скорость её полёта всегда одинакова?

23. Одно крупное предприятие выбрасывает в атмосферу 200 т сажи в год. После установки очистительных сооружений на этом предприятии количество выбросов сажи уменьшилось в 20 раз. Сколько тонн сажи выбрасывает предприятие в атмосферу после установки очистительных сооружений?

24. Одно большое дерево выделяет в сутки столько кислорода, сколько его необходимо для одного человека. В условиях города под влиянием загазованности выделение кислорода снижается в 10 раз. Сколько должно быть деревьев, чтобы обеспечить кислородом город в 250000 человек?

25. В сутки автомобиль способен выбросить в воздух примерно 20 кг выхлопных газов. Сколько выхлопных газов могут выбросить в воздух 8 автомобилей за 10 суток?

26. Для образования в природе слоя почвы толщиной 5 см требуется, по подсчётам учёных, 2000 лет. Сколько лет потребуется для образования слоя почвы в 12 см?

27. Из 1 т тряпья при переработке получают 600 м ткани. Сколько метров ткани можно получить из 25 т тряпья?

28. Большая синица уничтожает в день примерно 120 гусениц кольчатого шелкопряда, равных по массе 34 г. Чему равна масса гусениц кольчатого шелкопряда, съеденных синицей за лето и начало осени (июнь, июль, август, сентябрь)?

29. На территории Окского заповедника гнездятся сотни птиц. Пара поползней приносит своим птенцам в день 300 гусениц, пара дятлов - в 3 раза больше, чем пара поползней, а пара скворцов - в 5 раз больше, чем пара поползней. На сколько больше гусениц приносит своим птенцам пара скворцов, чем пара дятлов? 
30. Сова уничтожает за год 1000 полевых мышей. Сколько килограммов хлеба сохраняет в год одна сова, если одна полевая мышь в год запасает 1 кг зерна?

31. 31. Самые трудолюбивые санитары леса - муравьи. В среднем муравьи за 1 минуту приносят в муравейник 2 десятка насекомых. Сколько насекомых принесут муравьи за 1 час?

32. Высота горы Эльбрус 5642 м, что на 609 м больше горы Казбек. Определи высоту горы Казбек.

33. Жизненная ёмкость лёгких пловца 4900 куб. см, занимающихся греблей 5450 куб. см, офисного служащего 3350 куб. см. Сравни эти характеристики.

34. За сутки в среднем у собаки выделяется 200 куб. см. желчи, у овцы 400 куб. см. у коровы 4 л, у лошади - 5 л. На сколько (во сколько раз) больше желчи выделяет:
а) овца, чем собака;
б) корова, чем овца;
в) лошадь, чем собака?

35. За сутки в среднем кожа человека выделяет 800 г воды, почки - 1600 г, лёгкие - 400 г. На сколько больше воды выделяют почки, чем кожа и лёгкие вместе?

36. За сутки семиточечная коровка поедает 100 тлей. Одна самка коровки за лето может отложить 1000 яиц. Сколько тлей могут съесть коровки, выросшие из этих яиц?

37. За сутки семья одного муравейника ловит 15000 насекомых. Сколько насекомых оказались не съеденными, если в лесу были разорены три муравейника?

38. Высота самой высокой горы в мире Джомолунгмы - 8848 м над уровнем моря. Наибольшая глубина в океане - 11022 м. Каково расстояние между самой высокой и самой низкой точкой на Земле? 
39. Расстояние между крайней восточной и западной точками на карте края укладывается в 6 см, расстояние с севера на юг в 5 см, а наибольшая протяжённость с северо-запада и на юго-восток в 9см 5мм. Найдите сколько это составит километров, масштаб карты: в 1 см - 100 км.

40. Телецкое озеро самое глубокое озеро в Бийском крае. Найдите среднюю глубину озера, если она в 10 раз меньше, чем глубина озера Байкал - 1740 м. Найдите наибольшую глубину озера, если она на 151 м больше средней.

41. При движении Земли вокруг своей оси муха, сидящая в районе экватора, движется со скоростью 464 м/сек, а муха, сидящая на широте нашей местности, движется со скоростью в 2 раза меньшей. Какое расстояние проделает каждая из них за время полного оборота Земли вокруг своей оси? Выразить расстояние в километрах.

42. Одна муха откладывает 120 яичек. В течение лета каждая муха успевает дать не менее 7 поколений. Сколько мух может появиться от двух мух за лето?

43. Паук вырабатывал паутину 5 минут со скоростью 180 см/мин, а потом ещё 3 минуты. С какой скоростью паук вырабатывал паутину последние 3 минуты, если общая длина сотканной нити составляет 1500 см?

44. Самая большая высота Крымских гор 1545м. Уральские горы на 349 м выше Крымских, но ниже Карпатских на 769 м, которые ниже горы Эльбрус на 2970 м. Определи высоту горы Эльбрус.

45. 45.Один центнер макулатуры сберегает 8 сосен. Ребята собрали 3000 кг макулатуры. Сколько деревьев сохранили ребята и сколько книг выйдет, если одна книга весит в среднем 500 г?

46. Крымские горы имеют протяжённость 150 км, Карпатские в 10 раз большую, такую же, как и Кавказские, но на 600 км меньше, чем протяжённость Уральских гор. Определите протяжённость Уральских гор. 
47. Длина реки Днепр 2280 км. Днепр короче реки Дунай на 570 км, который короче реки Волги на 840 км. Определите длину реки Волги.

48. Самое глубокое озеро в мире, которое находится в России, Байкал. Его глубина 1740 м. Оно на 840 м глубже Каспийского моря. Вычислите глубину Каспийского моря.

49. Глубина Азовского моря 14 м. Это в 160 раз меньше глубины Чёрного моря, которое на 1780 м глубже Балтийского моря. Определите глубину Балтийского моря.

50. Известно, что гречиха хороший медонос. С одного гектара цветущих растений можно получить 60 кг мёда. Сколько мёда получат на пасеке с 50 гектаров поля, засеянного гречихой?

\section{Задачи на нахождение площади}

51. Самое большое озеро в мире, которое находится в России, называется Каспийское. Его площадь 400 кв. км, что на 368 кв. км больше площади озера Байкал. Определите площадь озера Байкал.

52. В Сингапуре есть фермы, где разводят креветок. Одна ферма со своей площади получила 9000 кг креветок, вторая 13500 кг. Площадь первой фермы на 5 га меньше, чем площадь второй. Какова площадь каждой фермы?

53. Площадь России - 17075 тыс. кв. км. Это 1/8 часть всей суши Земли. Найдите площадь всей суши Земли.

54. На Земле пустыни занимают $1 / 3$ всей суши. Найдите площадь суши, свободной от пустынь, если площадь всей Земли 14910000 кв. км.

55. Площадь Тихого океана 182600000 кв. км. Если бы он был прямоугольной формы и шириной 8000 км, то какова была бы длина этого прямоугольника и каков его периметр? 
56. Ледники на всей Земле занимают площадь 16000000 кв. км. Если начертить квадрат с такой же площадью, то какой будет его периметр?

57. Общую площадь суши можно попробовать представить как прямоугольник шириной 5000 км, длиной 29820 км. За последние 100 лет 1/7 территории суши стала непригодной для сельского хозяйства из-за почвенной и ветровой эрозии. Сколько это квадратных километров?

58. Ядро кометы Галлея было размером 16 х 8 км. Найдите его площадь.

59. Протяжённость реки Амазонки около 7000 км, а бассейн (территория, с которой стекают ручьи и реки в Амазонку) имеет около 7 млн. кв. км. Найдите ширину бассейна Амазонки и его периметр.

60. На 1 кв. см кожи груди человека 10 холодочувствительных точек. Сколько холодочувствительных точек на участке груди $12 \mathrm{x} 14$ см?

61. На 1 кв. см кожи ладони человека находится 4 холодочувствительные точки. Сколько холодочувствительных точек на участке ладони $5 \times 6$ см?

62. На 1 кв. см кожи носа человека 9 холодочувствительных точек. Сколько тепловых точек на 1 кв. см носа человека, если их меньше, чем холодочувствительных точек на участке носа 1 х 2 см?

63. Самое большое зарегистрированное стадо газелей имело длину 100 км, а ширину - на 136 км меньше. Вычислите площадь, которую занимало стадо газелей?

64. Смерчь - это сильный атмосферный вихрь. Он « всасывает», как пылесос, всё, что попадается по дороге. Такой вихрь в 1904 году в Москве оставил след шириной 80 м и площадью 3200000 кв. м. Каков периметр этого следа? 
65. На Луне есть диковинки. Одна из них - громадная расщелина, пересекающая лунные горы. Её назвали Альпийская долина. Ширина долины 10 км, длина - в 12 раз больше. Другая диковинка - Прямая стена высотой 500 м. Площадь боковой стороны Прямой стены на 1145 кв. км меньше площади долины. Найдите длину Прямой стены.

66. Астероид Эрос имеет небольшие размеры по сравнению с другими астероидами. Если его положить в Тихом океане, то получится остров длиной 21 км и шириной в 3 раза меньше. Найдите периметр и площадь этого острова? 


\section{МАТЕРИАЛ ДЛЯ СОСТАВЛЕНИЯ ЗАДАЧ ПРИРОДОВЕДЧЕСКОГО СОДЕРЖАНИЯ}

\begin{tabular}{|c|c|c|}
\hline Название породы & Высота дерева & $\begin{array}{c}\text { Средний возраст } \\
\text { жизни }\end{array}$ \\
\hline Ель & $30 \mathrm{~m}$ & 300 лет \\
\hline Лиственница & $53 \mathrm{~m}$ & 600 лет \\
\hline Сосна & $55 \mathrm{M}$ & 350 лет \\
\hline Пихта & $30 \mathrm{м}$ & 350 лет \\
\hline Берёза & $20 \mathrm{м}$ & 150 лет \\
\hline Дуб & $40 \mathrm{м}$ & 2000 лет \\
\hline Вяз & $40 \mathrm{м}$ & 400 лет \\
\hline Липа & $35 \mathrm{~m}$ & 500 лет \\
\hline Кедр & $45 \mathrm{~m}$ & 850 лет \\
\hline
\end{tabular}

\begin{tabular}{|l|c|l|c|}
\hline \multicolumn{1}{|c|}{ Название } & $\begin{array}{c}\text { Максимальный } \\
\text { возраст, лет }\end{array}$ & Название & $\begin{array}{c}\text { Скорость } \\
\text { полета, км/ч }\end{array}$ \\
\hline Щегол & 23 & Щегол & 28 \\
\hline Жаворонок & 24 & Вальдшнеп & 26 \\
\hline Озёрная чайка & 25 & Ворон & 38 \\
\hline Соловей & 25 & Ястреб & 40 \\
\hline Чайка & 45 & Чайка & 49 \\
\hline Сова & 60 & Сорока & 56 \\
\hline Аист & 60 & Зимородок & 72 \\
\hline Филин & 71 & Грач & 108 \\
\hline Лебедь & 70 & Голубь & 160 \\
\hline Орел-беркут & 104 & Стриж & Орёл \\
\hline Ворона & 120 & & \\
\hline
\end{tabular}




\section{Об экологии}

1. 1 га лиственного леса выделяет за сутки 2 кг фитонцидов; 1 га хвойного леса - 5 кг; 1 га можжевелового леса - 30 кг.

2. 1 га дубового леса продуцирует в год 830 кг кислорода, берёзового - 725 кг, соснового - 540 кг.

3. 1 га хвойного леса отфильтровывает в год 30-35 т пыли, лиственного леса - 50-70 т пыли.

4. Один дятел за день съедает до 750-900 короедов; кукушка съедает в день до 40 гусениц, 5 личинок майского жука, до 50 личинок щелкунов и чернолетов и др.; мухоловкапеструшка съедает за день до 300 мух и комаров.

5. Ежегодно на планете исчезают лесные массивы на площади 120000 кв. м.

6. Ежедневно на планете вырубается более 33000 га леса.

7. Ежедневно в джунглях всего мира под пилами падает 5 млн. деревьев.

8. Каждый гектар тропического леса выделяет ежегодно 28 т кислорода.

9. Вся растительность планеты за год «выдыхает» 175 млн. т биологически активных веществ.

10. Общая площадь лесов в мире составляет 19 млн.кв. км. 12 млн. кв. км приходится на зону тропиков, из них 10 млн. кв. км занимают широколиственные леса.

11. В Московской области на 1 га богатых перегноем полей живёт 4 млн.500 тыс. дождевых червей. За 200 суток они «перепахивают» 450 т грунта.

12. Насекомых на Земле более 1 млн. видов. Из них: жуки - 250 тыс. видов; бабочки - 140 тыс. видов; перепончатокрылые 90 тыс. видов; мухи и комары - 80 тыс. видов. 


\section{Из книги рекордов Гиннеса.}

\section{1. Самый большой обхват.}

В штате Оаксака, Мексика, гигантский кипарис Монтесумы высотой 41 м имел в 1982 году обхват 35,8 м на высоте 1,52 от земли. Имеются также баобабы, дающие в обхвате 54,5 м.

\section{2. Самые высокие.}

Самым высоким деревом была дугласова пихта, Британская Колумбия, 1902г. Её высота равнялась 126,5 м.

Самое высокое растущее в настоящее время дерево - горный ясень в Тасмании. Его высота - 99 м.

\section{3. Самый крупный тигр.}

Этого огромного индийского тигра убили в США в 1967г. Его длина 3,22 м, вес 388,7 кг. Сейчас он выставлен в американском Музее естественной истории, Вашингтон, США.

4. Самый большой и самый тяжёлый.

Самым длинным и самым тяжёлым млекопитающим в мире является голубой или желтовато-зелёный кит, также известный под названием кит-полосатик. Самой длинной особью считается самка кита, найденная на берегу Кампанья Аргентина в 1909 г., длина которой составляла 33,58 м. Другая самка, длиной 27,6 м, пойманная китобойной флотилией «Слава», весила 187 т. Её язык весил 4,22 т, сердце - 698,5 кг. Новорождённый детёныш кита имеет в длину 6,5- 8,6 м и весит до 2,95 т.

\section{5. Самое быстрое морское жсивотное.}

Самым быстрым морским животным является дельфинкасатка. 12октября 195 8г. Был обнаружен самец длиной 6,10-7,62 м, двигавшийся со скоростью 55,5 км/ч в восточных водах Тихого океана. 


\section{6. Самое быстрое жнивотное суии.}

Из животных суши быстрее вех преодолевает короткие расстояния (до 549 м) леопард, способный развивать скорость 96-101 км/ч по относительно ровной поверхности. Животное суши, быстрее всех преодолевающее большие расстояния ( более 914 м) - Вилорогая антилопа, обитающая в западной части США. Есть данные, по которым они пробегали 6 км со скоростью 56 км/ч, 1,6 км со скоростью 67 км/ч, 0,8 км со скоростью 88,5 км/ч.

7. Самый крупный представитель семьи кошачьих. Самый крупный представитель семьи кошачьих длинношерстный сибирский тигр, известный также как амурский тигр. Взрослый самец в среднем имеет в длину 3,15 м. Высота в холке 99-107 см, вес около 265 кг.

8. Самое маленькое плотоядное жсивотное.

Самым маленьким плотоядным суши является горностай, который обитает в Сибири. Взрослые особи имеют длину 177-207 мм и весят от 35 до 70 г.

9. Кто больше всех ест.

Больше всех в природе поглощает пищи мотылёк Полифемус, встречающийся в Северной Америке. В первые 48 часов жизни он поглощает количество пиши, которое в 86000 раз превышает его собственный вес при рождении. Если перевести эти данные на «язык людей», то оказалось бы, что только что появившийся на свет ребёнок весом в 3,17 кг съедал бы 273 т пищи.

\section{0. Рекорд высоты.}

Наибольшая высота, на которой могут летать птицы 8230 м. Именно на этой высоте пилот гражданского самолёта обнаружил 30 лебедей- крикунов.

\section{1. Самые летающие птицы.}

Самыми летающими из всех видов птиц считаются чёрные крачки, которые могут находиться в воздухе в течение 3-4 лет после вылета из гнезда в постоянном состоянии бессонницы до тех пор, пока не вернутся на землю для воспроизведения потомства. 


\section{2. Самые крупные птицы.}

Самой крупной летающей птицей является дрофа кори или пау, обитающая в Восточной и Южной Африке. Некоторые самцы весят до 18 кг. Лебедь мьют, обитающий в Британии, может тоже достигать 18 кг; в Польше был зарегистрирован лебедь - самец весом 22,5 кг, который не мог летать.

\section{3. Самые маленькие птицы.}

Самой маленькой птицей в мире является пчелиная колибри, обитающая на Кубе и острове Пайн. Взрослые самцы достигают в длину 57 мм, причём половина этой длины приходится на клюв и хвост. Весят они 1,6 г. Самая маленькая морская птица - малый буревестник. Взрослые особи имеют в среднем в длину 140 мм и весят около 28 г.

\section{4. Самый большой лес.}

Самой большой поросшей лесом территорией в мире являются обширные хвойные леса на территории России. Общая площадь лесов достигает 1100000000 га (25\% всех лесных запасов мира); 38\% из них занимает сибирская лиственница.

\section{Знаете ли вы, что:}

Самая длинная река в мире - река Нил

$-6671 \mathrm{\kappa M}$

Самая длинная река Южнной Америки - Амазонка

-6480 км

Самая длинная река Северной Америки - Миссисипи

$-6420 \mathrm{kM}$

Самая длинная река Азии - Янщзы

-5800 км

Самая длинная река Европь - Волга

$-3530 \mathrm{KM}$

Дунай

-2850 км

Эльба

$-1165 \mathrm{\kappa M}$

Влтава

-446 км 


\section{Задачи на уроках природоведения 4 класс \\ (на примере Республики Адыгея)}

\section{Наш край.}

1. Республиканский центр - г. Майкоп, находится на высоте 230 м над уровнем моря, а метеостанция- 212 м над уровнем моря. На сколько центр выше метеостанции?

2. Город Майкоп основан был в 1857 г. Сколько лет исполнится городу в этом году?

\section{Поверхность Земли}

1. Город Краснодар основан запорожскими казаками в 1793г., а город Майкоп в 1857 г. Какой город старше и на сколько?

2. Гора Чугуш - высотой 3240 м, а гора Фишт - 2867, гора Оштен - 2804. Какая гора самая высокая? Какая гора самая низкая?

\section{Вода в природе}

1. Главная река Адыгеи - Лаба, длина которой составляет 327 км, а река Белая составляет 265 км. На сколько километров река Белая короче реки Лаба?

2. Проделав путь в 146000 м Псекупс впадает в Кубань впадает, а река Афипс-96000 м. На сколько река Псекупс длиннее делает путь, чем река Афипс?

\section{Растения и животные леса.}

1. 60 кг макулатуры сохраняют от вырубки одно дерево, растушее в лесу свыше пятидесяти лет. Сколько деревьев сохранят учащиеся одной школы, собрав свыше 720 кг макулатуры? Сколько макулатуры надо собрать, чтобы сохранить 27 деревьев?

2. За сутки взрослый лось летом съедает до 35 кг корма, зимой всего 15 кг. На сколько килограммов корма меньше съедает лось зимой и почему? 
3. Медведица (бурая) в январе-феврале приносит 2-3-х медвежат, каждый из которых весит всего 500 г. Сколько весят два медвежонка; три медвежонка?

4. Лишайники обычно первыми заселяют безжизненные места. Растут лишайники медленно, в год на 8 мм, зато живут некоторые из них до 80 лет. На сколько сантиметров вырастет лишайник за 80 лет?

\section{Растения и жниотные полей}

1. Размножаемость сорных растений очень велика. Одно растение в год даёт зёрен: ржаной костёр 1420, василёк на 5260 больше, а полевой осот на 12920 больше, чем василёк. Вычислить, сколько зёрен даёт одно растение каждого из указанных сорняков в год?

2. За лето одна сова уничтожает до 1000 полевых мышей, а одна полевая мышь уничтожает 1 кг зерна. Сколько килограммов зерна за лето сохранят две совы, 20 сов?

\section{Земля - планета}

1. Окружность Земли равна 40000 км. До ближайшего города 100 км. Сколько раз нужно пройти это расстояние. Чтобы проделать путь, равный окружности Земли?

2. За какое время самолёт сможет облететь Землю, если скорость его 1000 км/ч?

3. Если было бы возможно совершить путешествие вокруг Земли пешком, делая по 25 км в сутки, сколько потребовалось бы суток, чтобы обойти Землю?

4. В разных частях земного шара в течение всего года сверкает молния и гремит гром. По данным статистики, в каждую секунду молния сверкает, а, следовательно, и гром гремит, не менее 100 раз. Сколько раз на всём земном шаре сверкает молния за 1 час? 


\section{На Крайнем Севере}

1. Вес белого медведя 500 кг. Сколько килограммов весят два таких медведя?

2. Длина тела белого медведя 3 м, а длина тела моржа длиннее, чем длина тела белого медведя?

\section{Тундра}

1. Если волк очень голоден, то он способен съесть сразу до 10 кг мяса. Сколько килограммов мяса съедят 10 голодных волков?

2. Скорость волка в случае опасности 55 км/ч. Сколько километров может пробежать волк с такой же скоростью за 3 часа?

\section{Лесная полоса}

1. Ондатры впервые завезены в Россию в 1928 году. Сколько лет прошло с тех пор, как впервые в нашей стране появились ондатры?

2. В особо неурожайные годы белки покидают родные места и двигаются туда, где есть корм. Они преодолевают сотни километров, двигаясь со скоростью 4 км/ч. За сколько часов они преодолеют 300 км?

3. Ласточки, жаворонки, оляпки, воробьи, иволги, сороки, скворцы относятся к отряду воробьиных. Кто из них живёт дольше и на сколько лет, если ласточка живёт 16 лет, жаворонок - 9 лет, оляпка - 8 лет, скворец - 20 лет, воробей 13 лет, иволга -15 лет и сорока - 45 лет?

\section{Cmenu}

1. Один хомяк запасает на зиму 800 г зерна. Сколько зерна уничтожат за зиму 2 хомяка, 20 хомяков?

2. Розовый скворец съедает 200 г саранчи в день. Сколько грамм саранчи уничтожат за 4 дня 1 скворец, 10 скворцов? 
3. Глубина проникновения в грунт корней картофеля 150 см, подсолнечника на 100 см глубже, сахарной свёклы на 50 см глубже, чем подсолнечника. Определите глубину проникновения корней подсолнечника и сахарной свёклы в грунт.

\section{Пустыни.}

1. Густая шерсть хорошо защищает верблюда от холода и жары. Он не требователен к пище - ест любые пустынные растения, пьёт солоноватую и солёную воду. Причём верблюд за один раз может выпить 57 л воды. Сколько литров воды выпьет он за 2 раза?

2. Одногорбый верблюд может развить скорость до 16 км/ч. Сколько километров пойдёт он за 5 часов? 


\section{ИСПОЛЬЗОВАННАЯ ЛИТЕРАТУРА}

1. Сухарев Ю.Ф. Природоведение. Учеб.-метод. Пособие к ученикам природоведения в $3-4$ классах общеобразовательных школ. К учебникам Плешакова А.А. - Чапаевск: Чипо, 2008. - 236 с.

2. Сергеева, Т.Ф. Информационно-категориальный подход к обучению математике детей дошкольного и младшего школьного возраста /Т.Ф. Сергеева. - Майкоп: Изд-во АТУ, 2001. - $160 \mathrm{c}$.

3. Багова Л.Л. Интегрированный подход к обучению предметам естественно-математического цикла в начальной школе: учеб.-метод. Пособие. - Майкоп: Изд-во ООО «Аякс», 2003. - 48 с.

4. Сухаревская, Е.Ю. Технология интегрированного урока: практ. пособие для учителей начальной школы, студентов пед. учеб. заведений, слушателей ИПК / Е.Ю. Сухаревская. - Ростов н/Д: Учитель, 2003. -128 с. 
Кагазежев Мурат Нурбиевич, Багова Ляна Левовна

\section{СБОРНИК ЗАДАЧ ПРИРОДОВЕДЧЕСКОГО СОДЕРЖАНИЯ}

Учебно-методическое пособие для учителей начальных классов

Усл. п.л. 2,8

Подписано к использованию 11.07.2016 г.

ООО «Электронные издательские технологии» 385020, Республика Адыгея, г. Майкоп, а/я 09 e-mail:elit-publishing@yandex.ru 